\title{
Microstructural characterization of ceramic artifacts made using the raku technique
}

\author{
Caracterização microestrutural de artefatos cerâmicos confeccionados com a técnica de raku \\ Caracterización microestructural de artefactos cerámicos realizados mediante la técnica raku
}

Received: 06/30/2021 | Reviewed: 07/06/2021 | Accept: 07/09/2021 | Published: 07/21/2021

Wilton Antônio Machado Júnior

ORCID: https://orcid.org/0000-0003-1689-6449

Universidade Federal de Itajubá, Brazil

E-mail: wiltonmachado1992@gmail.com

Maria Gabriela Araujo Ranieri

ORCID: https://orcid.org/0000-0001-8631-020X Universidade Federal de Itajubá, Brazil

E-mail: gabiranieri@unifei.edu.br

Rosinei Batista Ribeiro

ORCID: https://orcid.org/0000-0002-2150-4561

Centro Universitário Teresa D’Avila, Brazil

E-mail: rosinei1971@gmail.com

Jorge Luiz Rosa

ORCID: https://orcid.org/0000-0003-0305-8569

Universidade de São Paulo, Brazil

E-mail: jlrosa@demar.eel.usp.br

Adilson da Silva Mello

ORCID: https://orcid.org/0000-0002-1966-3686 Universidade Federal de Itajubá, Brazil E-mail: prof.adilsonmello@gmail.com

\begin{abstract}
This study was carried out at the atelier "Adamas", located in the city of Cunha, in the state of São Paulo, Brazil. The objective is to characterize the physical and mechanical properties of ceramics made using the raku technique in the Adamas atelier. As a methodology, the specimens were submitted to the following tests: Scanning Electron Microscopy (SEM), X-ray Energy Dispersion Spectroscopy (EDS), mass loss and linear shrinkage. It was observed that the specimens were mainly composed of silicon and aluminum, which is typical of ceramics made with kaolinitic clays, possessing a plastic behavior for molding and after firing refractory. Therefore, ceramic artifacts made through the raku technique have typical chemical and physical characteristics of clay ceramics, proper adhesion of the glaze even when there are crackles originated purposely from the process, which causes the artistic artifact appropriate characteristics for use and appreciation.
\end{abstract}

Keywords: Ceramic characterization; Ceramic artifact; Raku technique.

\section{Resumo}

Este estudo foi realizado no atelier “Adamas”, localizado na cidade de Cunha, estado de São Paulo, Brasil. O objetivo é caracterizar as propriedades físicas e mecânicas das cerâmicas confeccionadas pela técnica do raku no ateliê da Adamas. Como metodologia, os corpos-de-prova foram submetidos aos seguintes ensaios: Microscopia Eletrônica de Varredura (MEV), Espectroscopia de Dispersão de Energia de Raios-X (EDS), perda de massa e retração linear. Observou-se que os corpos-de-prova eram compostos principalmente de silício e alumínio, o que é típico de cerâmicas confeccionadas com argilas cauliníticas, possuindo um comportamento plástico para moldagem e após queima refratária. Portanto, os artefatos cerâmicos confeccionados através da técnica do raku possuem características químicas e físicas típicas da cerâmica argilosa, aderência adequada do esmalte mesmo quando há estalos originados propositalmente do processo, o que faz com que o artefato artístico tenha características adequadas para uso e apreciação.

Palavras-chave: Caracterização cerâmica; Artefato cerâmico; Técnica raku.

\section{Resumen}

Este estudio se llevó a cabo en el taller "Adamas", ubicado en la ciudad de Cunha, en el estado de São Paulo, Brasil. El objetivo es caracterizar las propiedades físicas y mecánicas de las cerámicas elaboradas con la técnica del raku en el atelier Adamas. Como metodología, las muestras se sometieron a las siguientes pruebas: Microscopía electrónica de barrido (SEM), Espectroscopía de dispersión de energía de rayos X (EDS), pérdida de masa y contracción lineal. Se observó que las probetas estaban compuestas principalmente por silicio y aluminio, lo cual es típico de las cerámicas elaboradas con arcillas caoliníticas, que poseen un comportamiento plástico para el moldeado y refractario después de 
la cocción. Por lo tanto, los artefactos cerámicos elaborados mediante la técnica del raku tienen características químicas y físicas típicas de las cerámicas de arcilla, adherencia adecuada del esmalte incluso cuando hay crepitaciones originadas intencionalmente en el proceso, lo que provoca que el artefacto artístico tenga características adecuadas para su uso y apreciación.

Palabras clave: Caracterización cerámica; Artefacto cerámico; Técnica raku.

\section{Introduction}

Ceramic art is present in the culture of the inhabitants of the city of Cunha, in the state of São Paulo, Brazil. The activity began with women known as "Paneleiras", who made ceramic household items in the early twentieth century. In 1975, a group of potters arrived in the city to make high temperature sintered ceramic artifacts (Da Silva, 2016). The municipality of Cunha has 21,639 inhabitants, and was founded in 1858 (IBGE, 2019), and currently has around 40 ceramic ateliers.

Potters use various techniques in their activities, such as raku, which has its origin in China, and later spread to Japan. This technique differs from others due to the crackles on the surface of the pieces. During the crafting process, after the modeling of the pieces, they are painted with engobe (clay-based tincture) and fired in an oven for eight hours, raising the temperature at a rate of $100^{\circ} \mathrm{C}$ per hour until reaching $800^{\circ} \mathrm{C}$ when the fire is put out. Subsequently, the piece is painted with glaze (liquid element composed of glass fragments and mixed dyes) and sintered at $1,000^{\circ} \mathrm{C}$ for one hour, after which time the it is removed from the kiln, conditioned in a sawdust container (ground wood) to cool and rinsed with running water. Some artifacts can be seen in Figure 1. (Huang \& Hsiao, 2019; Philippe Colomban, 2020).

Figure 1. (a) e (b) Ceramic artifacts made with the Raku technique.
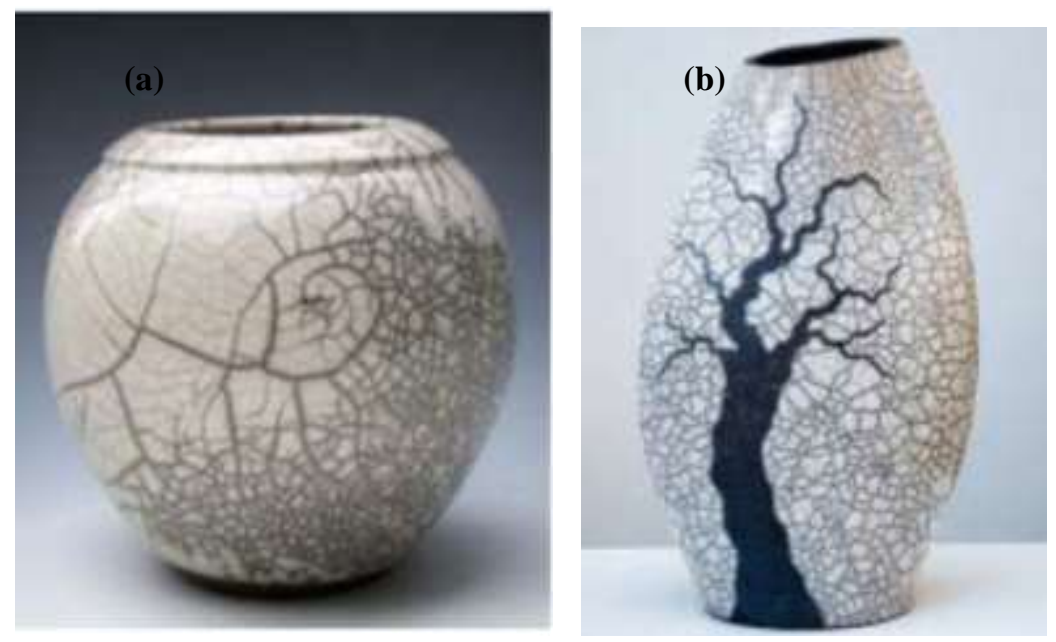

Source: Authors.

The Adamas atelier, inaugurated in 2004, is among the group that practices this technique, and it will serve as the object of study for this paper. The ceramist of this atelier collects the clays around the surrounding area of the city of Cunha, and uses both a wood-fired and gas-fired kiln, which were built by him. The wood-fired kiln is used for the first burn of eight hours and the gas-fired kiln is used for the second burn.

Thus, the objective of the research is to characterize the physical and mechanical properties of ceramics that are subjected to the raku technique. 


\section{Methodology}

This is a qualitative-quantitative research whose objective was to understand the relationship exists between the ceramist, his technology, his artifacts and his materials, that is, to understand the connections between human and non-human actors. Therefore it was necessary the involvement of social sciences, materials engineering and design to carry out this case study.

The specimens were made with the same raw material used by the potter in his usual craft activity and went through the same raku technique processes for ceramic artifacts. For the preparation of the specimens, a mixture of two clays (red and white) was used. The specimens were prepared in the atelier and subjected to Scanning Electron Microscopy (SEM), X-ray Energy Dispersion Spectroscopy (EDS), mass loss and linear shrinkage, at the laboratories of the University of São Paulo (USP) and the Teresa D'Ávila University (UNIFATEA). Specimen preparation occurred as described in Figure 2.

Figure 2. Process of making a ceramic artifact using the Raku technique.

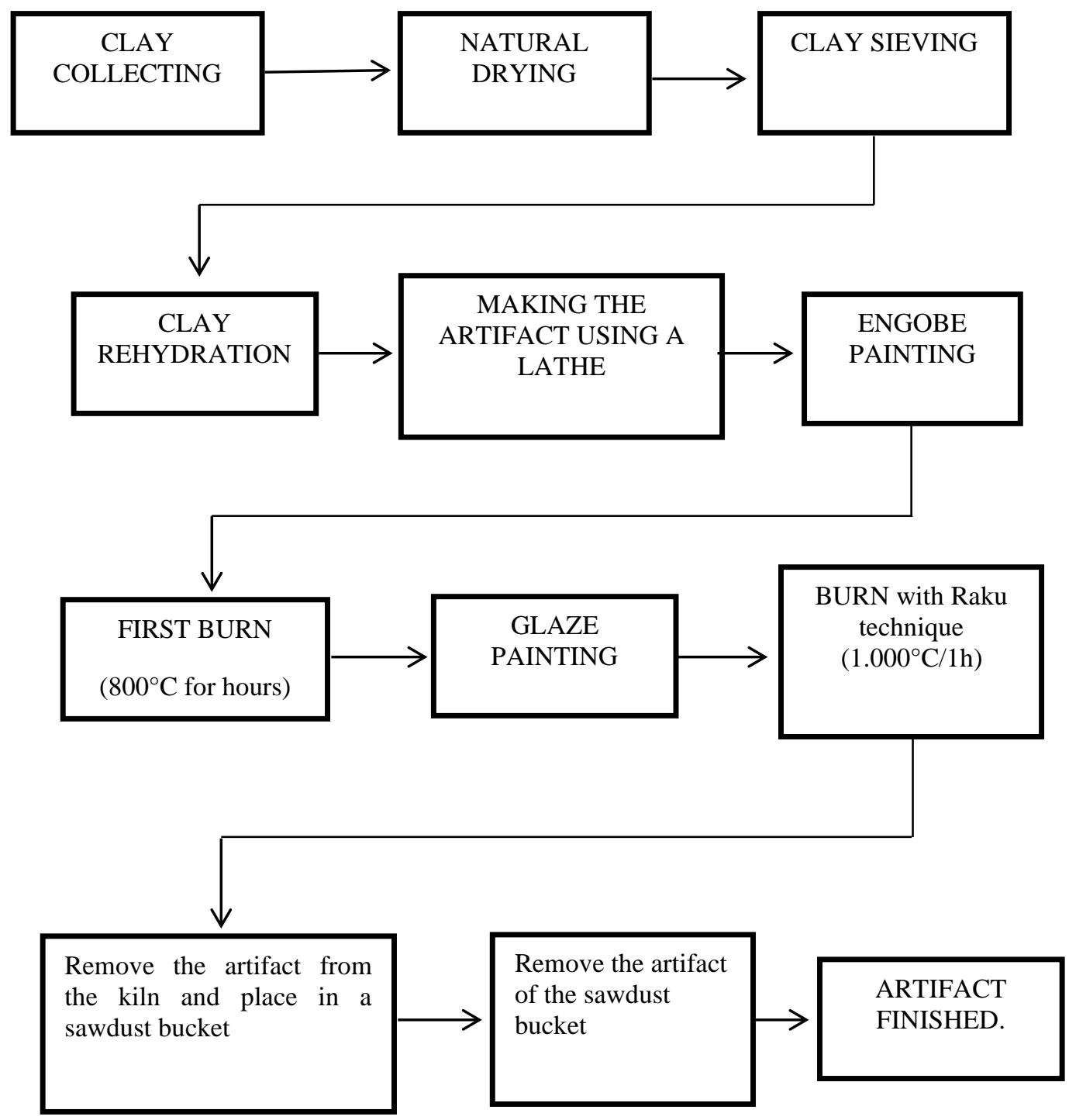

Source: Authors. 
To understand the characteristics of the specimens, two groups were created, one coated (with engobe and glaze) and one uncoated. Sixteen of the 33 specimens are coated and the other 17 were sintered uncoated. The number of specimens was defined following the recommendation seen in ASTM C674-13.

Scanning Electron Microscopy was used to analyze the ceramic material microstructures (producing images with high magnification and resolution) and acquire data on the topography, morphology and characterization of chemical elements present in the material. The Hitachi MEV, TM 3000, from the Electron Microscopy Laboratory of the Department of Materials Engineering at the University of São Paulo, was used. The SEM equipment is coupled with the EDS system, which allows the determination of the qualitative and semi-quantitative composition of the specimen, through the emission of characteristic $\mathrm{X}$ rays (Duarte et al., 2003).

In these tests, two types of specimens were observed in three situations, first a coated specimen with the micrograph initially directed to the specimen's ceramic support and then to the boundary region between the support, the engobe and the glaze; and another uncoated specimen with fracture-facing micrograph.

Through mass loss and linear shrinkage tests, the compactness of the specimens was analyzed in three moments: as raw clay, after the first sintering (at $800^{\circ} \mathrm{C}$ for 8 hours) and after the second sintering (the $1.000^{\circ} \mathrm{C}$ for one hour). In linear shrinkage, the length measurements $(\mathrm{mm})$ were analyzed by means of a caliper rule, with the measurement of the length of the specimens, before and after burning. The quotients between the difference in dimensions after the burns were analyzed. Mass loss and linear shrinkage tests were performed at the UNIFATEA Microbiology Laboratory, and the mass of the specimens was verified using an analytical balance. The linear shrinkage of the specimens was also identified using a digital type measuring instrument for comparative analysis of width, length and thickness.

\section{Results and Discussion}

With the SEM image it was possible to analyze the morphology and topography of the material used in the studied atelier. Figure 3 shows the micrograph of the coated specimen fracture.

Figure 3. SEM of coated specimen - central region.

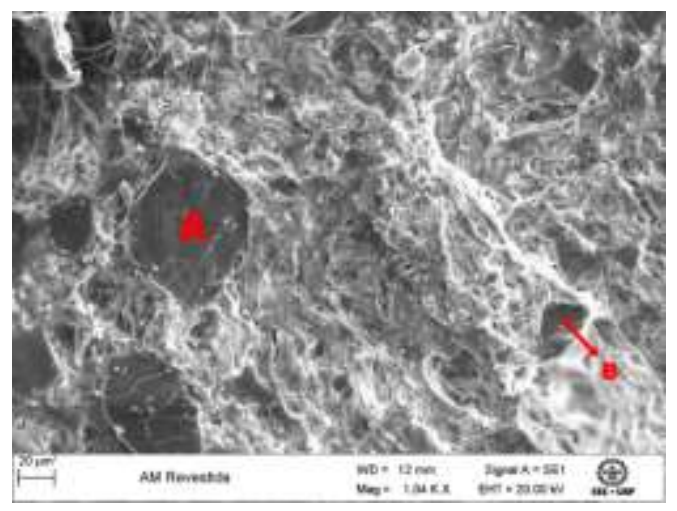

Source: Authors.

The quartz particles ( $\mathrm{SiO} 2)$ in (A), the porosity (B) of the ceramic material, with their cracks can be seen in the image. There is a significant amount of quartz particles, which is the main type of impurity present in clay, being a non-plastic raw material and inert in the sintering process (Macasaet, 2020; Norhayati Ayob, Mohamad, \& Arshad, 2021; Vieira, Monteiro, Barreto, Carvalho, \& Peiter, 2008).

In addition, quartz brings solidity to the ceramic during the firing process, attenuating the linear shrinkage and 
functioning as a skeleton, but increasing the porosity level. (Brito, Cunha, Machado, Silva, \& Nunes, 2015; Castro, Soares, Nascimento, \& Bison, 2015; Zanelli et al., 2019).

In the EDS test on the coated specimen, the ceramic support surface was first evaluated, as seen in Figure 4. The specimen is composed of silicon $(\mathrm{Si})$, aluminum $(\mathrm{Al})$, iron $(\mathrm{Fe})$, potassium $(\mathrm{K})$ and magnesium $(\mathrm{Mg})$. Based on the atomic weight, the elements are present in the following proportion: $\mathrm{Si}(65.70 \%), \mathrm{Al}(24.53 \%), \mathrm{Fe}(5.03 \%), \mathrm{K}(3.87 \%)$ and $\mathrm{Mg}$ $(0.86 \%)$. Therefore, the presence of $\mathrm{Si}$ and $\mathrm{Al}$, which are part of quartz and kaolinite, is mainly observed.

Figure 4. EDS made with coated specimen.

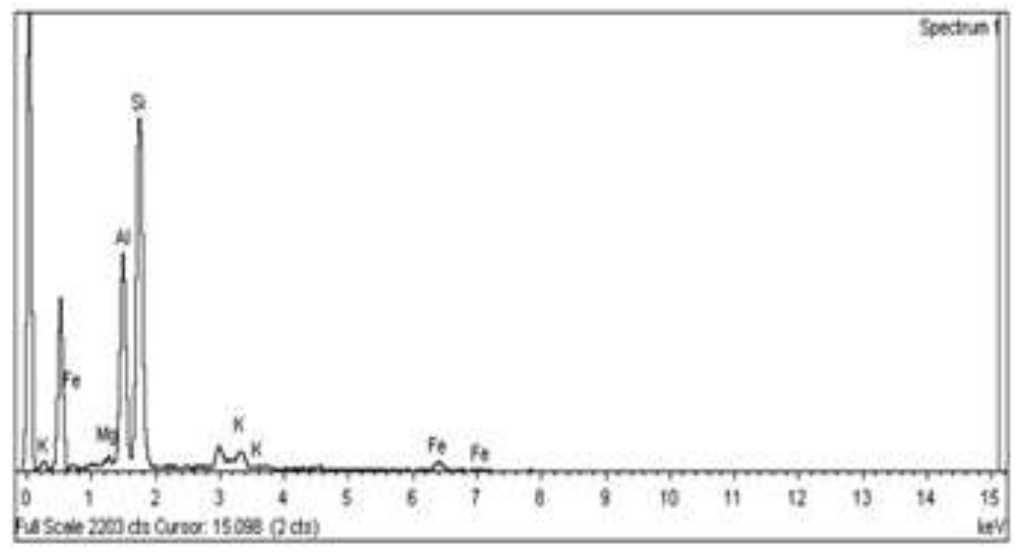

Source: Authors.

The uncoated specimen contains silicon, aluminum, iron, potassium, magnesium, as well as sulfur and calcium. Based on the atomic weight, the elements are: $\mathrm{Si}(56.32 \%), \mathrm{Al}(24.23 \%), \mathrm{Fe}(11.40 \%), \mathrm{K}(5.43 \%)$ and $\mathrm{Mg}(0,56 \%), \mathrm{S}(1.03 \%)$ and $\mathrm{Ca}(1.03 \%)$. It was observed that in both characterized specimens there is a significant presence of pores, defects, plane irregularities and a significant amount of quartz, characteristics of the microstructures of traditional ceramics (Vieira et al., 2008).

As for mass loss, the data were recorded in Table 1, where the values of the uncoated and coated specimens are present. The coated specimens had an increase in mass due to the addition of glaze, and it was necessary to separate the mass loss and linear shrinkage data to observe the differences in material behavior.

Table 1. Masses and mass loss of uncoated ceramic specimens.

\begin{tabular}{l|l|l|l|l|l}
\hline Samples & Raw clay $(\mathbf{g})$ & After 1 $^{\text {st }}$ burn $(\mathbf{g})$ & $\begin{array}{l}\text { Loss after } \mathbf{1}^{\text {st }} \\
\text { burn }(\boldsymbol{\%})\end{array}$ & $\begin{array}{l}\text { Loss after 2 } \\
\text { burn }(\mathbf{g})\end{array}$ & $\begin{array}{l}\text { Mass gain } 2^{\text {nd }} \\
\text { burn }(\boldsymbol{\%})\end{array}$ \\
\hline $\begin{array}{l}\text { Uncoated } \\
\text { Coating }\end{array}$ & 70.16 & 48.51 & $30.84 \pm 1.69$ & $52.53 \pm 3.56$ & $8.27 \pm 2.68$ \\
\hline
\end{tabular}

Source: Authors.

In the first burn the specimens had a considerable mass loss, both types of specimens consisted of the same elements, resulting in mass loss values close to $31 \%$ relative to the raw clays.

However, the specimens gained mass after the second firing when compared to the first firing. The uncoated specimens gained on average $8.27 \%$ and with a standard deviation of $2.68 \%$, while the specimens the average coated material gained $10.29 \%$ mass and a standard deviation of $1.94 \%$. In the first moment, the mass loss recorded after the first firing may be due to the elimination of organic material from the ceramic materials, which usually occurs at temperatures of approximately $900^{\circ} \mathrm{C}$. The specimens may have suffered a high degree of mass loss due to kaolinitic clay formation, because kaolinite has a 
significant amount of water in its composition (Hariz, Hariz, \& The, 2021; Salomão \& Oliveira, 2020;Vieira et al., 2008).

Subsequently, there was an increase in the mass of the specimens and the common factor in increasing the weight of both specimens was the sawdust contained in the bucket in which the specimens were deposited immediately after removal from the gas kiln. Specifically, for the coated specimen, the addition of glaze prior to the second firing process naturally increases the mass of these specimens. Data regarding linear shrinkage were recorded in Table 2

Table 2. Linear shrinkage data of uncoated specimens.

\begin{tabular}{c|c|c|c|c|c}
\hline Samples & Raw clay (mm) & $\begin{array}{c}\text { Linear } \\
\text { shrinkage after } \\
\mathbf{1}^{\text {st }} \text { burn }(\mathbf{m m})\end{array}$ & $\begin{array}{c}\text { Linear } \\
\text { shrinkage after } \\
\mathbf{1}^{\text {st }} \text { burn }(\boldsymbol{\%})\end{array}$ & $\begin{array}{c}\text { Linear } \\
\text { shrinkage after } \\
\mathbf{2}^{\text {st }} \text { burn }(\mathbf{m m})\end{array}$ & $\begin{array}{c}\text { Linear } \\
\text { shrinkage } \\
\text { after 2t } \mathbf{2}^{\text {st }} \mathbf{\text { burn }} \\
\mathbf{( \% )}\end{array}$ \\
\hline $\begin{array}{c}\text { Uncoated } \\
\text { Coating }\end{array}$ & 119.33 & 111.20 & $6.81 \pm 0.93$ & 105.17 & $5.39 \pm 0.99$ \\
\hline
\end{tabular}

Source: Authors.

It was observed that there was linear shrinkage in all specimens after the first firing. The general linear average shrinkage was $7.15 \%$ with a standard deviation of $1.23 \%$, considering that until the first firing the specimens have the same material. After the second firing, the uncoated specimens showed higher linear shrinkage, 5.39\% on average and with standard deviation of $0.99 \%$, while the coated specimens presented linear shrinkage of $4.82 \%$ and default of $0.69 \%$. The gradual increase in linear shrinkage is related to the higher degree of sintering and densification, which results in physical changes and decreased specimen volume (Abubakar, Muthuraja, \& Ahmad, 2020; Tsega, 2017; Brito et al., 2015; Rodrigues et al., 2014; Dal Bó, Melchiades, Bosch, \& Hotza, 2012; Luiz Fernando Teixeira Queiroz, 2009; Santos, Melchiades, \& Boschi, 2007; Galesi, Lepri Neto, Melchiades, \& Ortega Boschi, 2005; Tozi, 1992; Pérez, 1991; Parmelle, 1973).

\section{Conclusion}

Raku is a technique for ceramic firing, unique in its painting with engobe and glaze and the glass-like surface, in addition to the numerous crackles. The city of Cunha is closely linked to ceramic crafts, from the "Paneleiras" in the early twentieth century to the potters who arrived in 1975. Currently the city has more than 40 ateliers, and raku is among the numerous techniques used by its potters.

Based on the microstructure characterization analyses, the significant amount of pores, cracks and quartz particles in the specimens were identified by micrographs. Based on the EDS test, it was observed that the specimens were composed of silicon, aluminum, iron, potassium and magnesium. The presence of silicon and aluminum indicates the formation of kaolinite that has refractory behavior and is a plastic component. In addition, the glaze film was found to be composed of silicon and aluminum. The crackling occurs in the glaze fraction, originated by the difference in the coefficient of linear thermal expansion between ceramic support and glaze.

The mass loss in the first firing of the specimens was approximately $31 \%$, after the second firing the uncoated specimen gained $8.27 \%$, while the coated specimen gained $10.29 \%$. After the first burn, due to the elimination of organic material and the high degree of kaolinitic clay formation there is a significant loss of mass. The mass gain for uncoated specimens after the second firing is due to the absorption of sawdust contained in the bucket used to cool the artifacts after removal from the kiln, this fact may also explain the increase in mass of the coated specimens, remembering that these specimens were painted, naturally increasing their values even before the second sintering.

Regarding the linear shrinkage, the specimens presented an average retraction of $7.15 \%$. After the second firing, 
uncoated specimens retracted $5.39 \%$ and uncoated specimens $4.82 \%$. The gradual linear shrinkage of both specimens can be explained by the densification of the material at each sintering at higher temperatures.

Therefore, ceramic artifacts made by raku technique have typical chemical and physical characteristics of clay ceramics, proper adhesion of the glaze even with the presence of crackle purposely originated from the process, which causes the artistic artifact appropriate characteristics for use and appreciation.

Finally, future developments it is believed that it is essential to identify the sites of ceramics production and further studies on the different materials used by these artisans. It is also important to note the different technical variations and to know how to deal with the process of use of materials and burning. Another point that can be studied refers to the relationship between these practices and variations in the way of dealing with the raw material, in this case clay, and its relationship with consumers who visit the city.

\section{Acknowledgments}

The authors are very grateful to Coordenação de Aperfeiçoamento de Pessoal de Nível Superior (CAPES) for the scholarships granted to the co-authors - Process No. 1681743/2017, and the Adamas atelier and Mr. Luis Felipe Zúñiga Perez for all their support, understanding and availability.

\section{References}

Abubakar, M., Muthuraja, A., \& Ahmad, N. (2020). Experimental investigation of the effect of temperature on the density of kaolin clay. Materials Today: Proceedings, 41, 791-794. https://doi.org/10.1016/j.matpr.2020.08.565

Brito, V. L. O., Cunha, S. A., Machado, J. P. B., Silva, M. R., \& Nunes, C. B. (2015). Processing and characterization of a Ni-Co ferrite for sensor applications ( Processamento e caracterização de uma ferrita Ni-Co para, 61, 341-349.

Castro, R. J. S., Soares, R. A. L., Nascimento, R. M., \& Bison, E. C. (2015). Estudo do efeito do feldspato e resíduo de caulim na produção de revestimento cerâmico. Cerâmica Industrial, 20(1), 30-36. https://doi.org/10.4322/cerind.2015.003

Da Silva, K. J. (2016). A gênese de uma cultura ceramista. Ceramica, 62(361), 105-109. https://doi.org/10.1590/0366-69132016623611956

Dal Bó, M., Melchiades, F. G., Bosch, A. O., \& Hotza, D. (2012). Efeito das propriedades dos esmaltes e engobes sobre a curvatura de revestimentos cerâmicos. Ceramica, 58(345), 118-125. https://doi.org/10.1590/S0366-69132012000100019

Duarte, C., Juchem, P. L., Pulz, G. M., De, T. M. M., Chodur, N., Liccardo, A., \& Adicionais, I. (2003). Aplicações de Microscopia Eletrônica de Varredura (MEV) e Sistema de Energia Dispersiva (EDS) no Estudo de Gemas: exemplos brasileiros. Pesquisas Em Geociências, 30(2), 3-15.

Galesi, D., Lepri Neto, C., Melchiades, F., \& Ortega Boschi, A. (2005). Caracterização das Principais Argilas Utilizadas em Engobes para Revestimentos Cerâmicos. Cerâmica Industrial, 10(3).

Hariz, A. H., Hariz, A. H., \& The, D. U. (2021). Decoration Using The Clay Curd Technique To, 18(4), $7930-7938$.

Huang, Y. C., \& Hsiao, K. J. (2019). Research on image cognitive learning application: Taking Japanese raku ware as an example. ACM International Conference Proceeding Series, 228-232. https://doi.org/10.1145/3369199.3369206

IBGE. (09 de julho de 2021). In Instituto Brasileiro de Geografia e Estatística https://www.ibge.gov.br/cidades-e-estados/sp/cunha.html

Luiz Fernando Teixeira Queiroz. (2009). Efeito Da Quantidade De Areia Quartzosa No Processamento, Microestrutura E Propriedades Da Cerâmica Vermelha Para Telhas. Universidade Estadual do Norte Fluminense Darcy Ribeiro.

Macasaet, K. K. T. D. A. L. (2020). Utilization Of Settling Pond Clay Waste For Refractory Pottery. Angewandte Chemie International Edition, 6(11), 951952. College of Engineering and Geosciences, Caraga State University.

Norhayati Ayob, Mohamad, S., \& Arshad, S. E. (2021). Triangulation Clay Bodies Formulation for Lapohan Traditional Pottery. Journal of Educational Research \& Indigenous Studies, 3(1).

Parmelle, C. W. (1973). Ceramic Glazes. CBI Publishing Company Inc. (3st ed.) 386-418

Pérez, E. A. (1991). Apuntes de esmaltes y colores cerámicos. Cerámica Industrial, Instituto de Formación Profesional (2), Castellón, Spain.

Philippe Colomban. (2020). Glazes and enamels. In Angewandte Chemie International Edition, 6(11), 951-952. (Vol. 8233, pp. 1-26).

Rodrigues, L. dos S., Silva, J. C., Angélica, R. S., Rabelo, A. A., Portugal Fagury, R. L. R., \& Fagury Neto, E. (2014). Avaliação tecnológica de cerâmicas tradicionais incorporadas com rejeito do minério de manganês. Cerâmica, 60(356), 580-585. https://doi.org/10.1590/s0366-69132014000400018 
Research, Society and Development, v. 10, n. 9, e6910917755, 2021

(CC BY 4.0) | ISSN 2525-3409 | DOI: http://dx.doi.org/10.33448/rsd-v10i9.17755

Salomão, P. E. A., \& Oliveira, S. G. (2020). Estudo da resistência a compressão de cerãmicas sinterizadas por aquecimento convencional e microondas na presença de grafite. Research, Society and Development, 9(2), 14.

Santos, G. R., Melchiades, F. G., \& Boschi, A. O. (2007). Desenvolvimento de uma Metodologia para o Acompanhamento da Evolução do Amadurecimento de Engobes Durante a Queima. Cerâmica Industrial, 12(5), 22-27.

Tozi, N. (1992). Smalti Ceramici - Faenza Editrice Spa,(8), Faenza, Italy.

Tsega, E. (2017). Effects of Firing Time and Temperature on Physical Properties of Fired Clay Bricks. American Journal of Civil Engineering, 5(1), 21. https://doi.org/10.11648/j.ajce.20170501.14

Vieira, C. M. F., Monteiro, S. N., Barreto, C. G. W., Carvalho, E. A. de, \& Peiter, C. C. (2008). Substituição de areia de quartzo por finos de gnaisse em massa cerâmica para telhas: teste industrial. Cerâmica, 54(332), 480-486. https://doi.org/10.1590/s0366-69132008000400016

Zanelli, C., Ardit, M., Conte, S., Soldati, R., Cruciani, G., \& Dondi, M. (2019). Sinterização de porcelanatos com fluxo viscoso: Uma revisão. Cerâmica Industrial, 24(2), 7-12. https://doi.org/10.4322/cerind.2019.00 